\title{
Pilot Study on Low-density Binderless Bark Particleboards Manufacture from Gelam Wood (Melaleuca sp.) Bark
}

Eva Oktoberyani Christy, ${ }^{\mathrm{a}, *}$ Soemarno, ${ }^{\mathrm{b}}$ Sumardi Hadi Sumarlan, ${ }^{\mathrm{c}}$ and Agoes Soehardjono ${ }^{\mathrm{d}}$

\begin{abstract}
The production of low-density binderless bark particleboards (LDBBP) from gelam wood bark (GWB) using a hot pressing method at low temperature $\left(128{ }^{\circ} \mathrm{C}\right)$ and pressure $\left(30 \mathrm{~kg} \times \mathrm{cm}^{-2}\right)$ was explored by examining their physical properties according to SNI 03-2105-2006 (2006). They were also examined via scanning electron microscope (SEM)-energy dispersive X-ray (EDX) observation. The LDBBPs were manufactured using two types of GWB particles: (1) bark waste that was peeled off of small-diameter trees $<10 \mathrm{~cm}(\mathrm{~A})$ and, (2) bark that was directly peeled off from a standing tree with an average diameter of $10 \mathrm{~cm}$ to $15 \mathrm{~cm}(B)$. Results showed that the average values of the physical properties of $\operatorname{LDBBP}(\mathrm{A})$ and $\operatorname{LDBBP}(\mathrm{B})$ met the SNI 03-2105-2006 (2006) requirements in terms of density, moisture content, and thickness swelling after being immersed for $24 \mathrm{~h}$ for particleboard type 24-10 and type 17.510.5 with maximum thickness swelling requirement $20 \%$. However, they failed to meet the maximum thickness swelling criterion of $12 \%$ for other particleboard types. Subsequent internal morphology observation using SEM indicated the presence of cracks on LDBBP $(A)$, so only LDBBP $(B)$ could be manufactured without delamination. Gelam bark could potentially be used to produce non-adhesive particleboards.
\end{abstract}

Keywords: Gelam wood bark; Waste; Hot pressing; Valorisation, Low-density; Binderless bark particleboards; Physical properties

Contact information: a: Postgraduate Program, Faculty of Agriculture, Brawijaya University, Malang, Indonesia; b: Department of Soil Science, Faculty of Agriculture, Brawijaya University, Malang, Indonesia; c: Department of Agricultural Engineering, Faculty of Agricultural Technology, Brawijaya University, Malang, Indonesia; d: Department of Civil Engineering, Faculty of Engineering, Brawijaya University, Malang, Indonesia; *Corresponding author: eochristy28@gmail.com

\section{INTRODUCTION}

The Melaleuca species from the Myrtaceae family is native to Australia and Southeast Asia (Sakasegawa et al. 2003). It is an introduced species in the southern United States and South America (Tran et al. 2013). It is present in several Southeast Asian countries, which include Malaysia, Cambodia, Vietnam, Thailand, and Indonesia (Tran et al. 2013). In Indonesia, Melaleuca sp. is known by the local people as gelam. It grows naturally and is abundant in the Central Kalimantan, South Kalimantan, and South Sumatra coastal peat swamp forests (Supriyati et al. 2015).

Generally, in Indonesia, gelam timbers are used as wooden piles for constructing buildings, bridges, and roads. In addition, they are used as firewood, charcoal, and materials for making fences and chicken coops. The gelam wood used for such purposes is collected by wood gathering communities, one of which is located in the Pulang Pisau area of Central Kalimantan, which is a former target area of the Indonesian government's 
Million Hectare Mega Rice Project [Proyek Lahan Gambut Sejuta Hektar]. Moreover, they also collect gelam wood from the Kapuas area, as mentioned by Lasino and Witarso (2014). The transmigration area in Kapuas Regency, Central Kalimantan Province has significant local potential in the form of gelam forest (Melaleuca cajuputi), which covers an area of around 63,800 Ha. Selling gelam wood is the main livelihood of the local people. At the market, particularly at the level of collectors (traders), the number of gelam wood supply reaches no less than 2500 tree trunks per day with a diameter of 6 to $20 \mathrm{~cm}$ and length of $4 \mathrm{~m}$ (Lasino and Witarso 2014). They sell small-size gelam timbers $(\varnothing<10 \mathrm{~cm})$ without bark to build fences or chicken coops (Fig. 1d), and the outer bark of the gelam timber with a medium diameter $(\varnothing=10 \mathrm{~cm}$ to $15 \mathrm{~cm})$ is usually peeled off directly from a standing tree and used for roofs or to mend boats. According to Chiang and Wang (1984), Melaleuca has thick bark that is composed of many thin layers that comprises approximately $15 \%$ to $20 \%$ of the total stem volume. Abundant Melaleuca bark can cause problems when it is disposed of during timber harvesting seasons (Poole and Conover 1979). There are a number of environmental problems in Indonesia due to gelam wood bark (GWB) waste disposal. It renders the river water dirty, black, smelly, and silty, and it narrows the river mouth. In addition, the burning of the waste causes thick smoke that damages public health and disrupts access to public roads. To overcome such environmental problems, GWB waste must be turned into value-added products.

To improve the usage of Melaleuca sp. bark, several studies have been carried out in the context of both environmental and health care, in which bark from renewable, abundant, and inexpensive sources was used as lignocellulosic-biomass. Talib et al. (2014) examined the use of Melaleuca sp. bark as a green corrosion inhibitor, and Luo et al. (2015) studied their use as supercapacitors. Veeramani et al. (2015) studied the use of Melaleuca sp. bark for practical electrochemical vanillin detection, and Xiao et al. (2014) investigated the use of porous carbon materials for hydrogen storage. In addition, Melaleuca sp. bark was used for lithium-sulphur batteries (Zhu et al. 2019), bioethanol (Ahmed et al. 2013a), thermic, hydraulic, and dielectric devices (Roussan 1923), particleboard with ureaformaldehyde adhesive (Purwanto 2015), and high-density bark board without adhesive (Sato 2008). In this study, GWB was made into low-density binderless bark particleboard (LDBBP). There has not been any prior research on the manufacture of low-density binderless particleboards made from GWB.

For the production of bark particleboards without adhesives, Blanchet et al. (2000) and Claude et al. (2008) reported an approach based on particle plasticization (physical consolidation) and extractive polymerization for bark particle self-bonding. Burrows (1960) demonstrated how particleboards made from Douglas-fir bark particles could be manufactured at pressing temperatures below $180{ }^{\circ} \mathrm{C}$ with a mat moisture content of 12 to $20 \%$. In particular, the conditions were approximately $138^{\circ} \mathrm{C}$ and pressing pressures of 3 MPa without adhesives through the plasticisation mechanism. Such a mechanism may take place because bark is a lignocellulosic material and due to the availability of water as plasticizer. According to Almusawi et al. (2016), some lignocellulosic components with lightweight molecules such as lignin polymers, non-crystalline cellulose, and hemicellulose allow softening at a temperature suitable for producing a plasticized matrix that can connect particles in self-bonding particleboard. Such amorphous polymer softening basically requires a particular temperature and depends on the moisture content. Morsing (2000) mentions that the softening behavior of an amorphous polymer is marked by glass transition temperature $\left(T_{\mathrm{g}}\right)$, which is known as softening temperature. 
According to Pintiaux et al. (2015), glass transition temperature decreases as moisture content increases. Therefore, this plasticizing effect is considered as an important aspect when determining the right pressing temperature for producing panel products without synthetic adhesives in order to achieve the desired bonding. This is the same as performed by Burrows (1960) when producing a particle board without synthetic adhesives, in which he used a pressing temperature above the softening temperature of Douglas-fir bark, which could result in board properties that are comparable to those of commercial boards. It must be noted that the softening temperature of Douglas-fir bark varies according to the moisture content, as shown by a study by Chow (1980), in which the softening temperatures for materials with moisture content of $0 \%, 9.7 \%$, and $14 \%$ were $180{ }^{\circ} \mathrm{C}, 120{ }^{\circ} \mathrm{C}$, and $70{ }^{\circ} \mathrm{C}$, respectively. By applying a suitable pressing temperature, plasticization can take place in amorphous polymers and flow in such a way as to reach a high degree of mechanical contact or closeness (a few microns, at least) between the surface of particles or fibers intended to be adhesive and sufficient contact area, as proposed by Hubbe et al. (2018). Therefore, such mechanical contact becomes one of the critical links that can be recommended for the development of bonding in hot-pressed products by self-bonding or natural adhesives. With respect to the production of LDBBP from GWB, lignin, which is one of the flowable matrix components, is also present in the outer bark of Melaleuca sp. in a moderate amount. It was confirmed by Ahmed et al. (2013b) who report that Melaleuca leucadendron shedding bark contains $47.2 \%$ glucan, 17.4\% xylan, 19.13\% lignin (determined as acid-insoluble lignin and acid-soluble lignin), and 9.2\% extractives. According to Pintiaux et al. (2015), the presence of lignin, albeit at a low level, is beneficial in the production of binderless boards. Therefore, it is recommended that GWB be used as a material for producing non-adhesive particle boards. In this study, a manufacturing process involving low temperature and pressure was carried out to produce LDBBP from GWB.

This pilot study was an initial step to ensure that GWB can be manufactured into LDBBP via the hot pressing process. In order to ensure this, the physical properties of LDBBP were first investigated with an emphasis on thickness swelling (TS) and water absorption (WA) tests. TS is an important parameter for demonstrating the dimensional stability of a composite board product. This is because, according to Mantanis and Papadopoulus (2010), dimensional stability or more exactly the dimensional instability, as the case may be is the main disadvantage of wood-based panels (particle boards, MDF, or OSB) in terms of their final usage. This is related to moisture effect, where Halligan (1970) mentions that moisture effect in a particle board has an important influence on its properties and usages. When a particle board undergoes a change in moisture content, its strength is reduced and its lifespan is shortened, thus limiting its usage for exterior and structural purposes. Besides that, the moisture effect in a material is measured based on TS and WA (Baskaran et al. 2019), particularly TS, which is one of the requirements in various composite board testing standards. One of such standards involving the TS criterion is the Indonesian National Standard (Standard Nasional Indonesia or SNI) 03-2105-2006 (2006) for particle boards which is used in LDBBP testing. Besides that, LDBBP characterization was also carried out by means of SEM-EDX observation. Therefore, the objective of this study was to determine the possibility of manufacturing LDBBP by examining the physical properties and morphology of the resultant boards. 


\section{EXPERIMENTAL}

\section{Materials}

The gelam wood bark in this research was gathered from gelam wood collecting sites in Garung Village of the Pulang Pisau Regency in Central Kalimantan in the form of bark waste that was peeled from Melaleuca viridiflora Sol. Ex Gaertn. trunks with a diameter ( $\varnothing)$ of $<10 \mathrm{~cm}$ (Fig. $1 \mathrm{~b}$ and Fig. 1c). For comparison purposes, samples of gelam bark were taken directly from standing Melaleuca leucadendra (L.) trees with diameters of $10 \mathrm{~cm}$ to $15 \mathrm{~cm}$. Both GWB types were then identified by the Indonesian Institute of Science (the Centre for Plant Conservation and Botanical Gardens). In this study, there was no separation between the outer bark and the inner bark. Based on field observations, the gelam bark from the $\varnothing<10 \mathrm{~cm}$ trunk was thin (Fig. 2a), and the bark from the $\varnothing=14.5$ $\mathrm{cm}$ trunk had multiple layers with a thickness of approximately $3 \mathrm{~cm}$ (Fig. $2 \mathrm{~b}$ ).

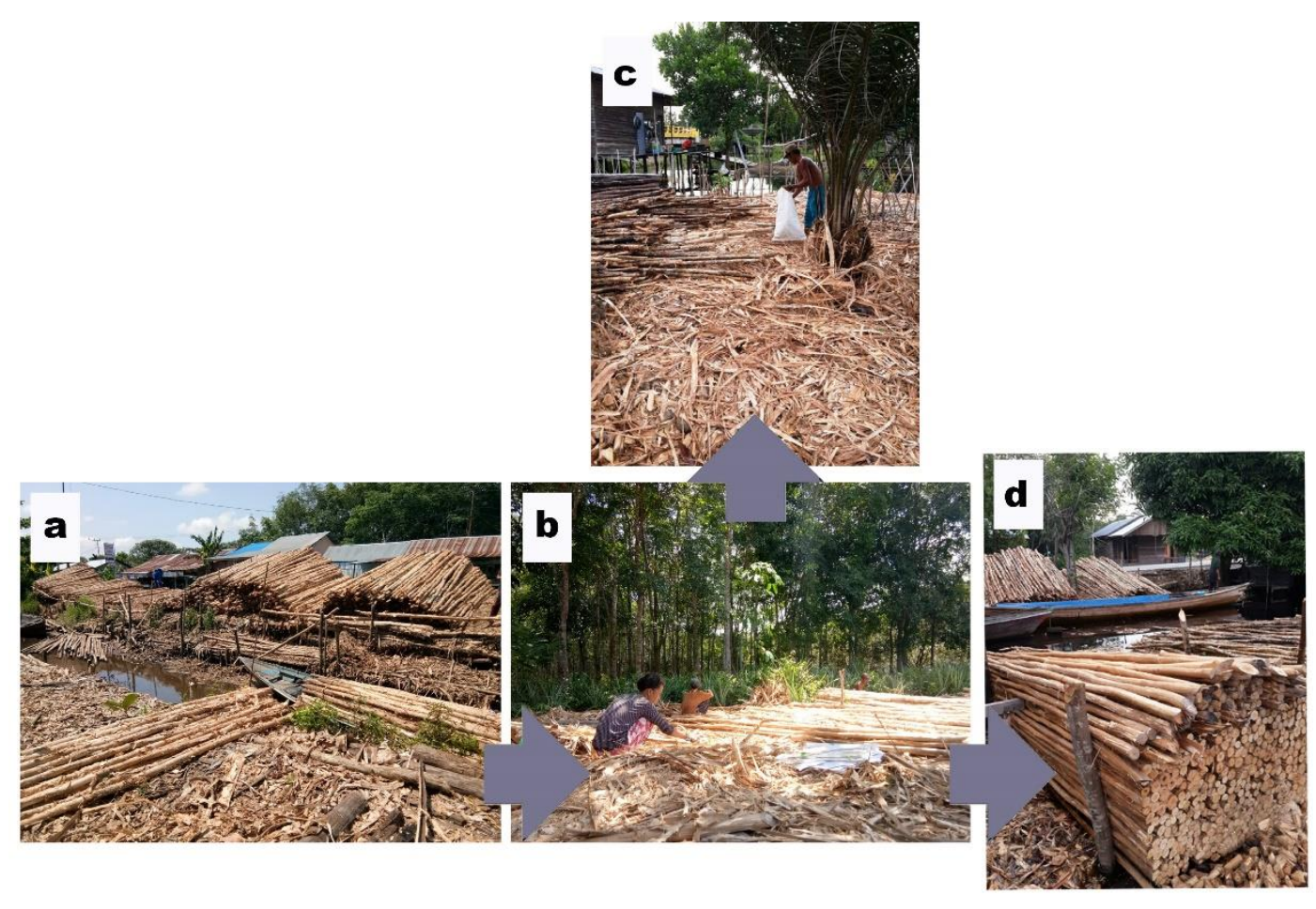

Fig. 1. Gelam bark waste flow: (a) gelam wood $(\varnothing<10 \mathrm{~cm})$; (b) gelam bark peeled from the trunk $(\varnothing<10 \mathrm{~cm})$; (c) gelam bark waste (in landfills and rivers); (d) gelam wood trunks $(\varnothing<10 \mathrm{~cm})$ after peeling

\section{Preparation of bark particles}

Two types of GWB particles were prepared from (1) trunk peel waste $(\varnothing<10 \mathrm{~cm})$ and (2) trunk peels $(\varnothing=10 \mathrm{~cm}$ to $15 \mathrm{~cm}$ ) (Fig. 2a and Fig. 2b), whose outer bark showed a whitish powdery layer which covered dark brown layers (Fig. 2c and Fig. 2d). Both types were cut into small pieces $( \pm 2 \mathrm{~cm} \times 2 \mathrm{~cm})$ using scissors. The particles were then air-dried until reaching a constant water content of $10 \%$ to $13 \%$. Then, the resultant particles were ground using a blender and sifted to obtain particles $<10$-mesh in size (Fig. 2e and Fig. $2 \mathrm{f})$. The resultant particles were then immediately placed into plastic bags to maintain their water content. 


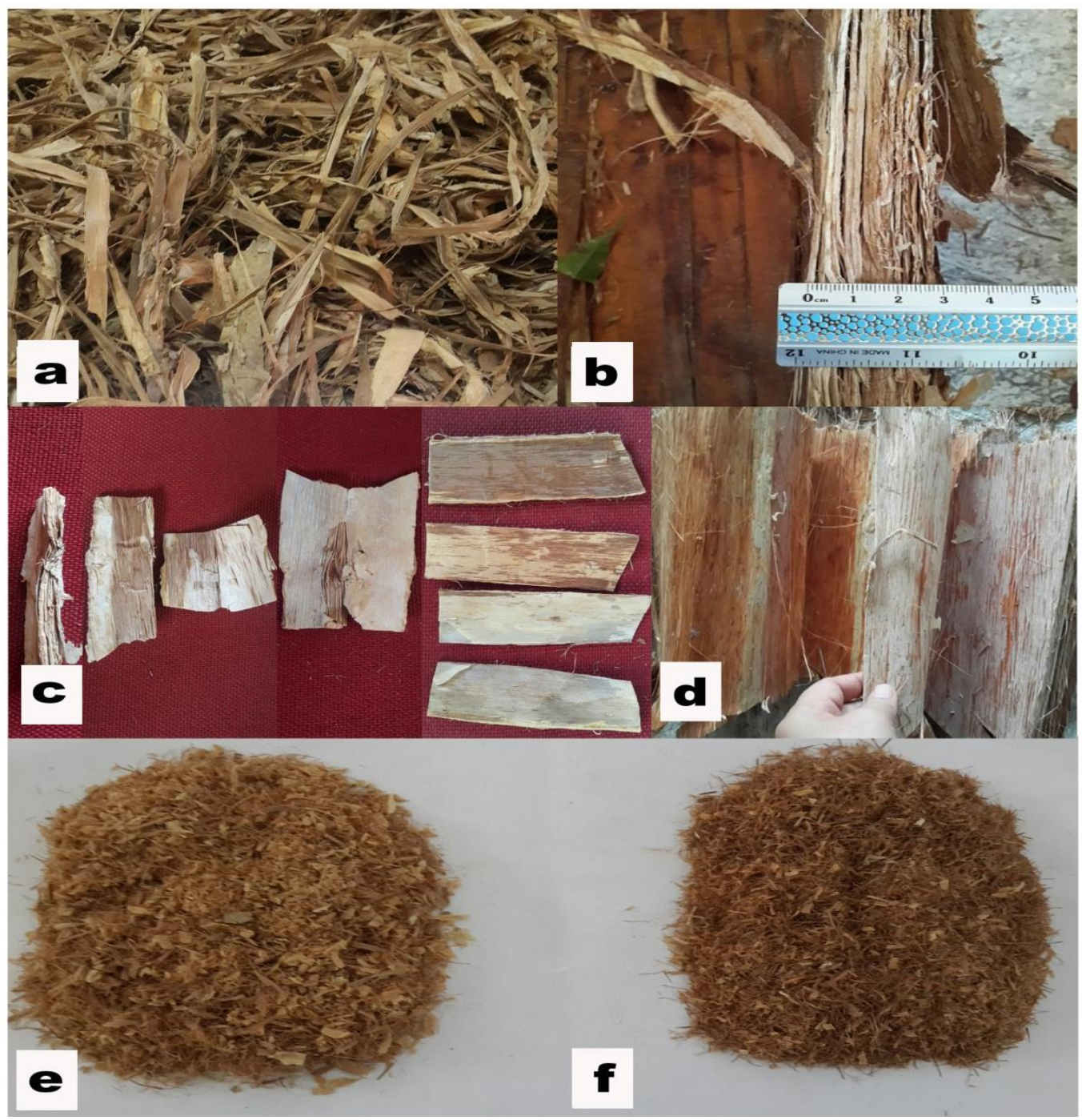

Fig. 2. Photographs of bark peeled off from the (a) $\varnothing<10 \mathrm{~cm}$ trunk and (b) the $\varnothing 14.5 \mathrm{~cm}$ trunk, a whitish powdery layer which covers dark brown layers in the outer bark peeled off from (c) $\varnothing<$ $10 \mathrm{~cm}$ trunk and (d) $\varnothing=10 \mathrm{~cm}$ to $15 \mathrm{~cm}$ trunk, and particles obtained from the bark peeled off from (e) $\varnothing<10 \mathrm{~cm}$ trunk and (f) the $\varnothing=10 \mathrm{~cm}$ to $15 \mathrm{~cm}$ trunk

\section{Production of LDBBP from GWB}

Two types of LDBBP were produced from two types of GWB particles from trunk peel waste $(\varnothing<10 \mathrm{~cm})$ and trunk peels $(\varnothing=10 \mathrm{~cm}$ to $15 \mathrm{~cm})$. In this study, each LDBBP was a $300 \mathrm{~mm} \times 300 \mathrm{~mm}$ single-layer panel with a thickness of $15 \mathrm{~mm}$ and a target density

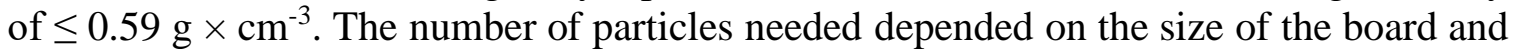
the target density. Based on this preliminary research, the weight of the bark particles prepared to reach a target density of $\leq 0.59 \mathrm{~g} \times \mathrm{cm}^{-3}$ was $810 \mathrm{~g}$. A mat was produced by using a base made of aluminium-zinc plate and placing thick bars on all four sides, each of which was $300 \mathrm{~mm}$ long and $15 \mathrm{~mm}$ thick. Above the thick bars, a forming box $(300 \mathrm{~mm}$ $\times 300 \mathrm{~mm} \times 100 \mathrm{~mm}$ ) was placed. The raw material was poured into the forming box. The material was then flattened and compressed manually. The forming box was then lifted. The upper part was closed with an aluminium-zinc plate. Pre-pressing via the cold pressing method was performed for 1 min. Hot pressing was carried out nonstop with a low temperature $\left(128{ }^{\circ} \mathrm{C}\right)$ for $20 \mathrm{~min}$ by applying $30 \mathrm{~kg} \times \mathrm{cm}^{-2}$ pressure. The resulting LDBBP 
was removed from the hot pressing machine (CHPM 100; Assembled in Bandung, Indonesia) (Fig. 3) and immediately put in a clamp for $24 \mathrm{~h}$ to avoid blowing, after which the clamp was opened, and the LDBBP was released from the aluminium-zinc plate. Then, it underwent the air-drying process at a relative humidity of $25{ }^{\circ} \mathrm{C}$ to $30{ }^{\circ} \mathrm{C}$ and $60 \%$ to $65 \%$ for $14 \mathrm{~d}$. This was conducted before the sample assessment.

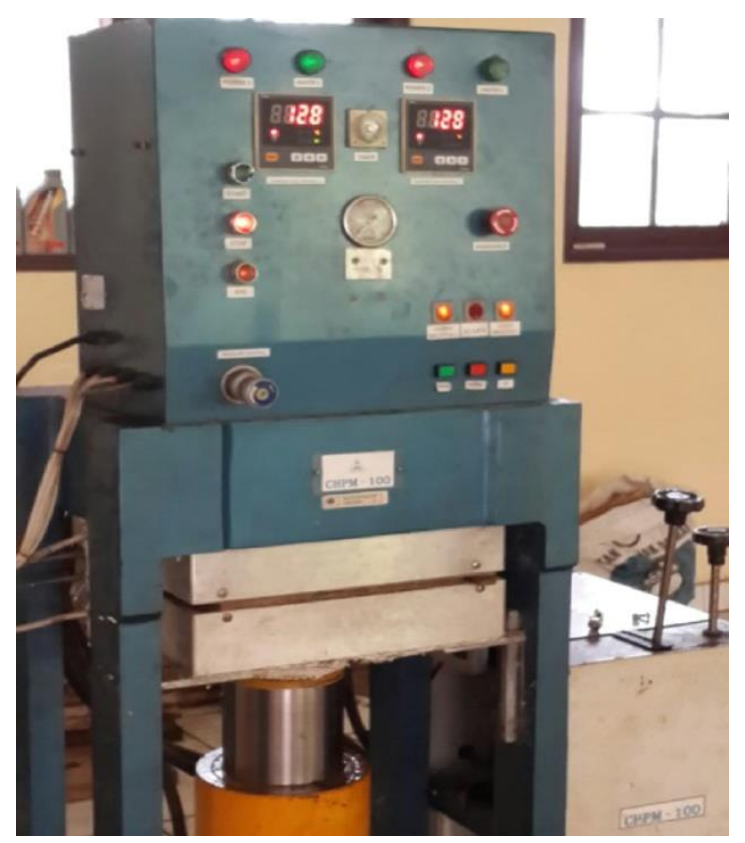

Fig. 3. The hot press machine

\section{LDBBP Physical Properties Assessment}

One LDBBP was manufactured for each board type. Three specimens were extracted for each board type to assess their density, moisture content (MC), thickness swelling after $24 \mathrm{~h}$ immersion (TS-24h), and water absorption after $24 \mathrm{~h}$ immersion (WA$24 \mathrm{~h})$. This assessment of the physical properties of LDBBP was performed according to SNI 03-2105-2006 (2006). Though WA value is not required by this standard, WA was also measured to determine the specimen's resistance to water in relation to their potential use as interior or exterior boards.

Three samples, each with a size of $100 \mathrm{~mm} \times 100 \mathrm{~mm}$, were used for each density and MC test. Density is the weight of each test sample divided by its volume. In this study, density was calculated based on weight and volume at air dry condition. Each sample's volume was obtained by measuring (1) both of its length sides and both of its width sides (25 mm away from the sample's edges with an accuracy of $0.1 \mathrm{~mm}$ ) and (2) its thickness at all four corners ( $25 \mathrm{~mm}$ away from the actual corners), i.e., the intersection of the corresponding length and width as described in point with an accuracy of $0.05 \mathrm{~mm}$. Density tests were performed with an accuracy of $0.1 \mathrm{~g}$. Water content was the difference between each sample's initial weight and its weight after it had undergone the oven-drying process until reaching a constant weight at a temperature of $105^{\circ} \mathrm{C} \pm 3{ }^{\circ} \mathrm{C}$.

Three samples, each with a size of $50 \mathrm{~mm} \times 50 \mathrm{~mm}$, were used to assess TS-24h and WA-24h. The test samples were immersed in water horizontally at a temperature of 25 ${ }^{\circ} \mathrm{C} \pm 1{ }^{\circ} \mathrm{C}$ at a depth of approximately $3 \mathrm{~cm}$ below the water surface for $24 \mathrm{~h}$. The thickness 
and weight of each sample were measured before and immediately after soaking. This method was used to calculate TS-24h and WA-24h. The results were expressed as the percentage of thickness and weight before soaking. Each sample's TS-24h was measured at all four corners (10 $\mathrm{mm}$ away from its actual edges). Then, the mean and standard deviation calculated from the data for each experiment. The standard deviation displayed as error bars in each corresponding figure.

\section{Scanning Electron Microscopy (SEM)}

Observations were also performed using a Carl-Zeiss (Evo MA 10, Cambridge, UK) scanning electron microscope at $60 \times, 300 \times$, and $1000 \times$ magnification, and it was equipped with energy dispersive X-ray spectroscopy (EDX) to examine the morphology and elemental compositions of the LDBBP in the cross-sectional areas. Before the SEMEDX test was performed, the samples were covered with Au-Pd (Emitech SC7620 mini sputter coater; Quorum Technologies Ltd., Lewes, UK).

\section{RESULTS AND DISCUSSION}

\section{LDBBP Appearance}

The surfaces of the LDBBP types were two different colours (Fig. 4a and Fig. 4b). The type A LDBBP had a whitish, light brown colour, and LDBBP (B) had a dark brown colour. This colour difference was due to the fact the particleboards were made from different raw materials; the GBW particles from trunk peel waste $(\varnothing<10 \mathrm{~cm})$ had a brighter shade than those of the GBW particles made from trunk peels $(\varnothing=10 \mathrm{~cm}$ to 15 $\mathrm{cm}$ ). The former was derived from thin bark, whereas the latter derived from thick bark with multiple layers.
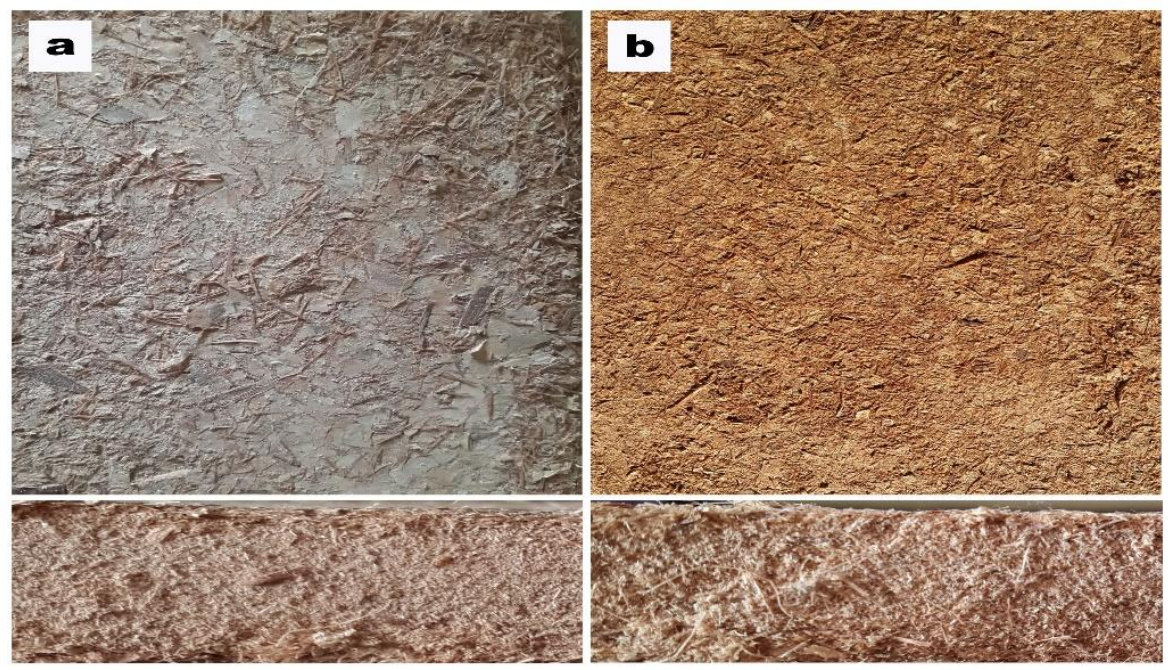

Fig. 4. The surface and cross-sectional appearance of LDBBP made from (a) trunk peel waste $(\varnothing<10 \mathrm{~cm})$ and $(\mathrm{b})$ trunk peels $(\varnothing=10 \mathrm{~cm}$ to $15 \mathrm{~cm})$

The white tinge on LDBBP (A) was probably due to the presence of fine particles that had escaped the 10-mesh filtration and were mixed with the whitish powders contained in their original material. Meanwhile, on LDBBP (B), the whitish powder could not be 
clearly observed on the board's surface because of the dominating dark brown color due to its many dark brown layers, marked by crude fibers which were present every 2 to $4 \mathrm{~mm}$ in the outer bark. Further, living bark also had a darker brown colour. The dark brown layers in the outer bark were also observed by Chiang and Wang (1984) in their research on the structure and formation of Melaleuca bark.

\section{Physical Properties}

The average density, MC, TS-24h, and WA-24h of the type A and B boards are shown in Fig. 5.
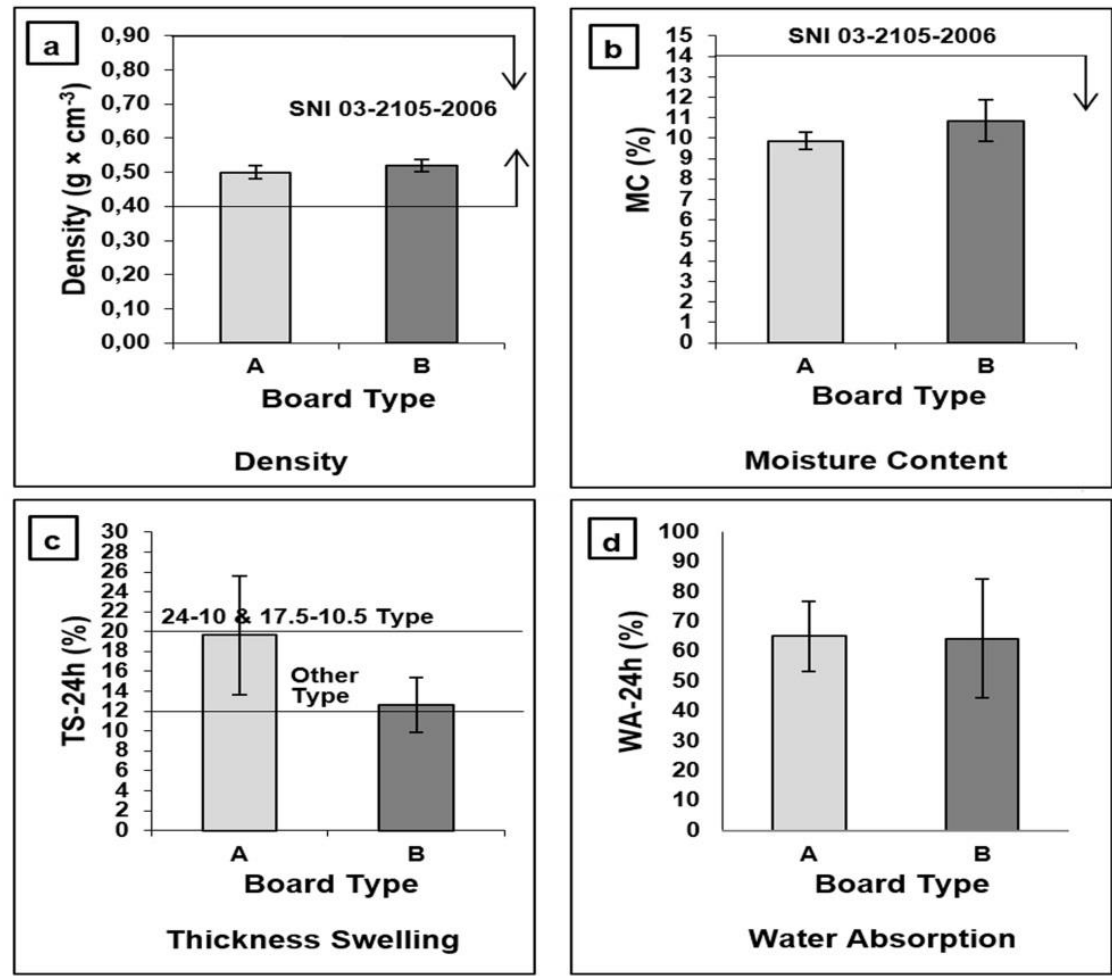

Fig. 5. Physical properties of LDBBP: (a) Density; (b) Moisture Content; (c) Thickness swelling; (d) Water Absorption (mean values and error bar indicate standard deviations); A: LDBBP (A)board was made from the GWB particles derived from (trunk peel waste $\varnothing<10 \mathrm{~cm}$ ); B: LDBBP (B) - board was made from GWB particles derived from trunk peels $(\varnothing 10 \mathrm{~cm}$ to $15 \mathrm{~cm})$

The average values obtained from the density tests were $0.50 \mathrm{~g}^{\circ} \mathrm{cm}^{-3}$ for LDBBP type A and $0.52 \mathrm{~g}^{\circ} \mathrm{cm}^{-3}$ for LDBBP type B. Both board types were classified as low-

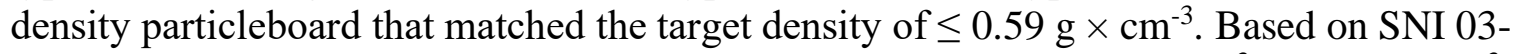
2105-2006 (2006), the requirement of particleboard density is $0.4 \mathrm{~g} \times \mathrm{cm}^{-3}$ to $0.9 \mathrm{~g} \times \mathrm{cm}^{-3}$. The density of all LDBBPs produced in this study met the specified standards.

The average values of moisture content were $9.87 \%$ for type A and $10.85 \%$ for type $\mathrm{B}$, thus fulfilling the requirements of SNI 03-2105-2006 (2006).

LDBBP type B has a TS-24h mean value of $12.66 \%$ which tends to be lower than that of LDBBP type A (19.62\%). Meanwhile, with regard to WA-24h, both LDBBP type $A$ and LDBBP type B tend to have mean values that are not markedly different at $65.09 \%$ and $64.31 \%$, respectively. Based on the water resistance results, both samples expanded but were not destroyed by water (Fig. 6). 


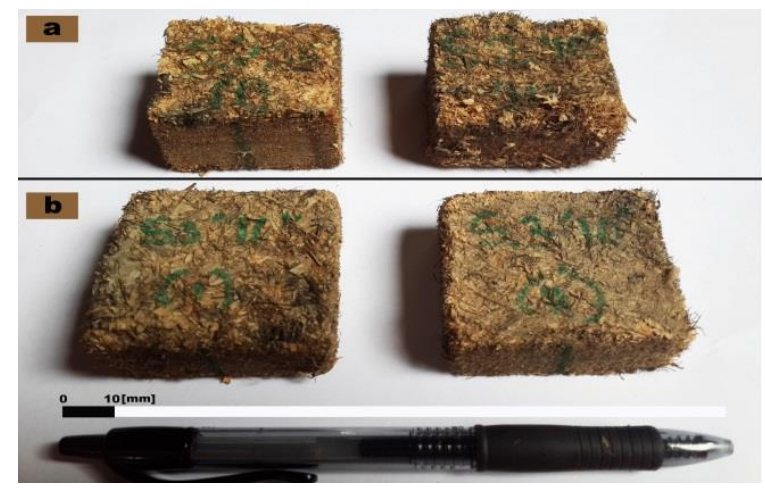

Fig. 6. Thickness swelling samples after $24 \mathrm{~h}$ of soaking (a) LDBBP B; (b) LDBBP A

The two LDBBP types both had relatively low TS-24h values and relatively high WA-24h values. According to various research, Melaleuca leucadendron bark is spongy and water-resistant (Leite and Pereira 2017), gelam bark possesses high wax content (Talib et al. 2014), and Melaleuca bark consists of many layers of suberised cells (Chiang and Wang 1984). Though the presence of hydrophobic wax and suberin might prevent the absorption of water by GWB particles, the water might enter the cavities of the LDBBP, where voids and cracks are characteristic of low-density boards (Fig. 7a and Fig. 7b). A similar tendency was found in a study by Kurokochi and Sato (2015); the TS (16\%) and WA (around $72 \%$ ) values of binderless boards made from rice straw (whole powder) with a target density of $0.80 \mathrm{~g} \times \mathrm{cm}^{-3}$ after 24-h immersion was mentioned in this study because there was a wax-like substance on the surface of rice straws that was highly water resistant. This resulted in binderless boards with relatively high water resistance regardless of low Internal Bonding.

Table 1. Physical Properties of LDBBP from GWB and Other Bark-based Boards

\begin{tabular}{|c|c|c|c|c|}
\hline Raw Material & $\begin{array}{l}\text { Density } \\
\left(\mathrm{g} \times \mathrm{cm}^{-3}\right)\end{array}$ & $\begin{array}{l}\text { TS-24h } \\
\text { (\%) }\end{array}$ & $\begin{array}{l}\text { WA-24h } \\
(\%)\end{array}$ & Reference \\
\hline $\begin{array}{c}\text { GWB peeled from trunks with a } \\
\text { diameter of }<10 \mathrm{~cm}^{\text {a }}\end{array}$ & 0.50 & 19.62 & 65.09 & Present work \\
\hline $\begin{array}{l}\text { GWB peeled from trunks with a } \\
\text { diameter of } 10 \mathrm{~cm} \text { to } 15 \mathrm{~cm}^{\mathrm{b}}\end{array}$ & 0.52 & 12.66 & 64.31 & Present work \\
\hline Melaleuca bark ${ }^{\mathrm{c}}$ & $0.80^{*}$ & 0.50 to 3.00 & 8.00 to 15.00 & Sato 2008 \\
\hline $\begin{array}{c}\text { Galam tree bark (Melaleuca } \\
\text { leucadendra L.) }\end{array}$ & 0.77 & 2.00 & - & $\begin{array}{l}\text { Purwanto } \\
2015\end{array}$ \\
\hline Quercus cerris bark ${ }^{\mathrm{e}}$ & $0.55^{*}$ & 8.45 & - & $\begin{array}{l}\text { Lakreb et al. } \\
2018\end{array}$ \\
\hline \multicolumn{5}{|c|}{$\begin{array}{l}\text { Without adhesive; pressing temperature and pressure: } 128^{\circ} \mathrm{C} \text { and } 30 \mathrm{~kg} \times \mathrm{cm}^{-2} \text { for } 20 \mathrm{~min} \text {; } \\
\text { particle size: escaped 10-mesh filtration; LDBBP }(\mathrm{A}) \\
\text { Without adhesive; pressing temperature and pressure: } 128^{\circ} \mathrm{C} \text { and } 30 \mathrm{~kg} \times \mathrm{cm}^{-2} \text { for } 20 \mathrm{~min} \text {; } \\
\text { particle size: escaped 10-mesh filtration; LDBBP (B) } \\
\text { Without adhesive; pressing temperature and pressure: } 180^{\circ} \mathrm{C} \text { and } 40.79 \mathrm{~kg} \times \mathrm{cm}^{-2} \text { for } 10 \\
\text { min and } 15 \mathrm{~min} \text {; bark flakes were made using a chipper; mesh size: } 50 \mathrm{~mm} \times 100 \mathrm{~mm} \text {; } \\
\text { single layer; high-density bark binderless board } \\
15 \% \mathrm{UF} \text { resin; pressing temperature and pressure: } 110^{\circ} \mathrm{C} \text { to } 120{ }^{\circ} \mathrm{C} \text { and } 15 \mathrm{~kg} \times \mathrm{cm}^{-2} \text { for } \\
15 \mathrm{~min} \text {; galam bark pieces } 6 \mathrm{~cm} \text { in length; single layer; medium-density particleboard } \\
10 \% \mathrm{PF} \text { resin; pressing temperature and pressure: } 170^{\circ} \mathrm{C} \text { to } 180^{\circ} \mathrm{C} \text { and } 8.16 \mathrm{~kg} \times \mathrm{cm}^{-2} \text { to } \\
71.38 \mathrm{~kg} \times \mathrm{cm}^{-2} \text { with the total pressing time } 15 \text { min; single layer; low-density particleboard } \\
\text { Target density }\end{array}$} \\
\hline
\end{tabular}


Comparisons between LDBBP (A), LDBBP (B), and other bark-based boards with and without adhesive are shown in Table 1 . The comparisons with high-density binderless barkboards (Sato 2008), medium-density particleboards (Purwanto 2015), and low-density particleboards (Lakreb et al. 2018) indicated that the TS-24h values of LDBBP (A) and (B) were higher than those of all other boards. Further, their WA-24 values were higher than those of high-density binderless boards. This probably was caused by the porous nature of low-density boards, which absorb more water than high-density boards do. In addition, both types of LDBPP had a relatively good water resistance considering the fact that the low-density particleboards were manufactured via hot pressing at low temperature and pressure without adhesive. The TS-24h values of LDBBP (A) and (B) only met the SNI 03-2105-2006 (2006) requirements for an ordinary structural particleboard (types 2410 and 17.5-10.5). Neither LDBBP type fulfilled the requirements for other board types (maximum 12\%) (Table 2). However, before the particleboards are put to structural use, further research needs to confirm their mechanical properties and determine whether they meet the SNI 03-2105-2006 (2006) requirements for type 24-10 and type 17.5-10.5 particleboards. The physical properties of LDBBP determined in this research might open up new research avenues to improve the dimensional stability of LDBBP. In addition, the self-bonding mechanism warrants further study.

To improve the dimensional stability of a non-adhesive board, raising the pressing temperature is one of the methods and parameters often proposed in the literature. This method is also recommended by Hashim et al. (2011), who found that increasing the pressing temperature from $160{ }^{\circ} \mathrm{C}$ to $200{ }^{\circ} \mathrm{C}$ could increase the board's dimensional stability. This is in spite of the fact that the value of TS-24h (18\%) and WA-24h (around $66 \%$ ) at $200{ }^{\circ} \mathrm{C}$ of binderless particleboard made from an oil palm trunk was still within the range of TS24h value of LDBBP (A) and (B) and slightly higher than the WA24h value of both LDBBP types. The same recommendation was also proposed by Panyakaew and Fotios (2011) for the production of low-density binderless coconut husk insulation boards, in which the pressing temperature was increased from $180{ }^{\circ} \mathrm{C}$ to $220^{\circ} \mathrm{C}$, while the TS was reduced. As also performed by Sato (2008) on high-density binderless bark boards that use a pressing temperature at $180{ }^{\circ} \mathrm{C}$.

Table 2. Maximum Thickness Swelling of Particleboards According to SNI 03-2105-2006 (2006)

\begin{tabular}{|c|c|c|}
\hline Particleboard Type & $\begin{array}{c}\text { Particleboard Thickness } \\
(\mathbf{m m})\end{array}$ & $\begin{array}{c}\text { Maximum Thickness } \\
\text { Swelling } \\
(\%)\end{array}$ \\
\hline $24-10$ & $\leq 12.7$ & 25 \\
\hline & $>12.7$ & 20 \\
\hline $17.5-10.5$ & $\leq 12.7$ & 25 \\
\hline & $>12.7$ & 20 \\
\hline 8 (with urea formaldehyde \\
adhesive) & Unconditional & Unconditional \\
\hline Other type & Unconditional & 12 \\
\hline
\end{tabular}

\section{SEM-EDX Analysis}

The SEM micrographs of both types of binderless bark particleboards are shown in Fig. 7a and Fig. 7b. Voids were common in LDBBP (B) (Fig. 7b). In addition, there were 
cracks on LDBBP (A) (Fig. 7a). However, these cracks were not readily observable in the surface and cross-sectional photographs of the boards (Fig. 4a).

As shown in Table 3, the EDX analysis of both types of binderless bark particleboards detected carbon and oxygen as dominant elements. In addition, small amounts of calcium, silicon, aluminium, magnesium, chlorine, and potassium were detected. The similarity in chemical composition of the particleboard types (the sizable amounts of carbon and oxygen) was probably due to the fact the GWB (the original material from which the boards were made) contained holocellulose, alpha cellulose, lignin, and extractive. These results were also found by Nadhari et al. (2014) in panels made from $100 \%$ oil palm trunk particles and $100 \%$ Acacia mangium particles.

Table 3. Analysis of LDBBP Chemical Elements

\begin{tabular}{|c|c|c|c|c|c|c|c|c|}
\hline \multirow{2}{*}{$\begin{array}{c}\text { Board } \\
\text { Types }\end{array}$} & \multicolumn{9}{|c|}{ Element (wt\%) } \\
\cline { 2 - 9 } & C K & O K & Ca K & Si K & Al K & Mg K & CI K & K K \\
\hline LDBBP (A) & 50.02 & 45.56 & 2.10 & 0.62 & 0.60 & 0.57 & 0.54 & - \\
\hline LDBBP (B) & 53.18 & 45.95 & 0.30 & - & - & - & 0.49 & 0.08 \\
\hline
\end{tabular}
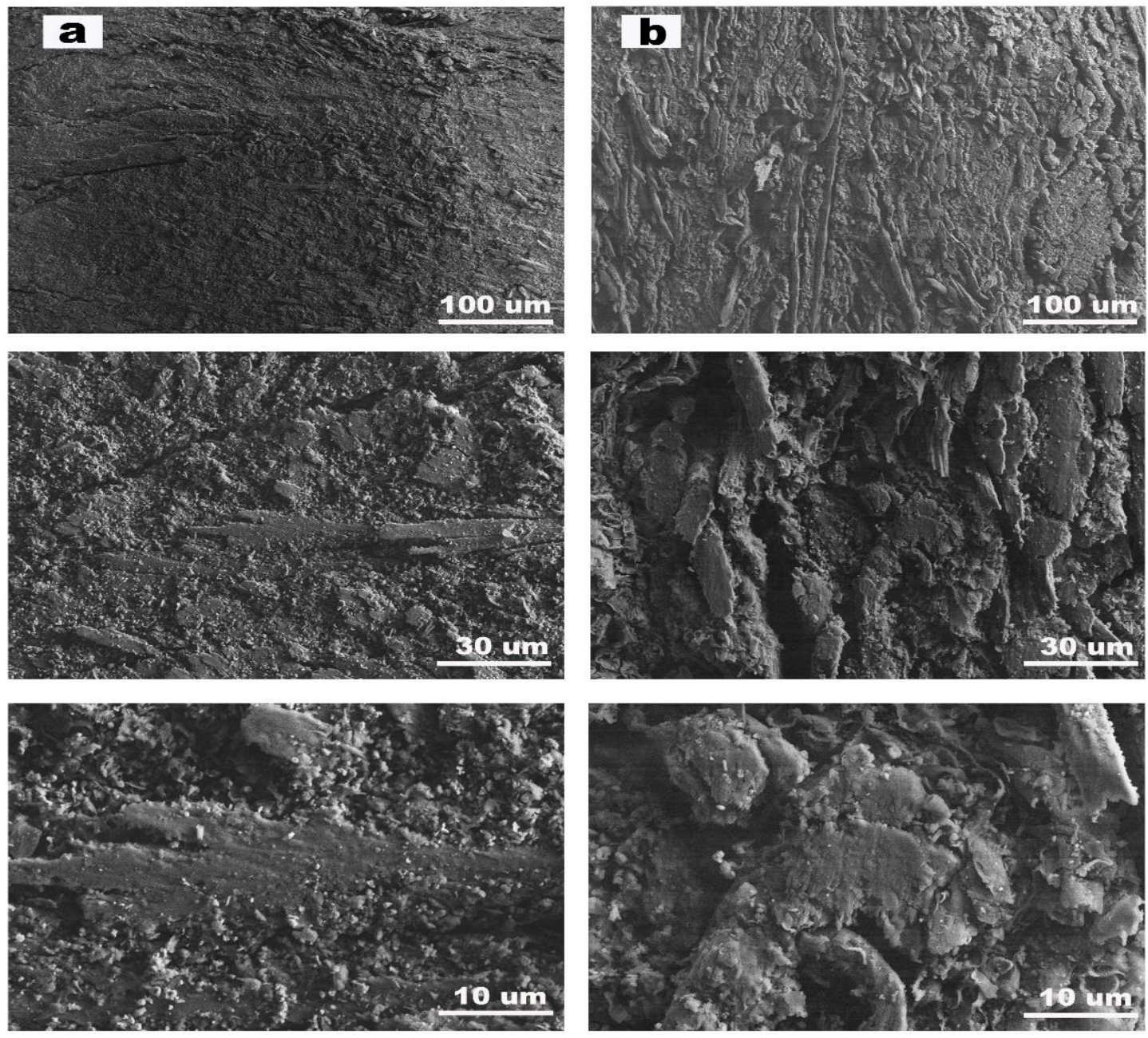

Fig. 7. Scanning electron micrographs of the cross-section of (a) LDBBP (A) and (b) LDBBP (B) at different magnifications 


\section{CONCLUSIONS}

1. It was possible to manufacture a single-layered LDBBP (B) via hot pressing at low temperature and pressure without delamination, while the internal morphology (crosssection) of LDBBP (A) showed some cracks.

2. Both particleboard types met the SNI 03-2105-2006 (2006) requirements for density, moisture content, and thickness swelling for types 24-10 and 17.5-10.5 (maximum $20 \%$ ). However, they did not meet the maximum requirements for other thickness swelling types (maximum $12 \%$ ).

3. The hydrophobic nature of the gelam wood bark produced LDBBP with sufficient water resistance relative to their low board densities.

\section{ACKNOWLEDGMENTS}

The authors thank the Ministry of Research, Technology, and Higher Education of the Republic of Indonesia for providing them with a postgraduate scholarship.

\section{REFERENCES CITED}

Ahmed, I. N., Nguyen, P. L. T., Huynh, L. H., Ismadji, S., and Ju, Y.-H. (2013a). "Bioethanol production from pretreated Melaleuca leucadendron shedding bark Simultaneous saccharification and fermentation at high solid loading," Bioresource Technology 136, 213-221. DOI: 10.1016/j.biortech.2013.02.097

Ahmed, I. N., Sutanto, S., Huynh, L. H., Ismadji, S., and Ju, Y.-H. (2013b). "Subcritical water and dilute acid pretreatments for bioethanol production from Melaleuca leucadendron shedding bark," Biochemical Engineering Journal, 78, 44-52. DOI: 10.1016/j.bej.2013.03.008

Almusawi, A., Lachat, R., Atcholi, K. E., and Gomes, S. (2016). "Proposal of manufacturing and characterization test of binderless hemp shive composite," Intl. Biodeterioration \& Biodegradation. 115, 302-307. DOI: 10.1016/j.ibiod.2016.09.011

Baskaran, M., Hashim, R., Sulaiman, O., Awalludin, M. F., Sudesh, K., Arai, T., and Kosugi, A. (2019). "Properties of particleboard manufactured from oil palm trunk waste using polylactic acid as a natural binder," Waste and Biomass Valorization 10(1), 179-186. DOI: 10.1007/s12649-017-0026-7

Blanchet, P., Cloutier, A., and Riedl, B. (2000). "Particleboard made from hammer milled black spruce bark residues," Wood Science and Technology 34(1), 11-19. DOI: 10.1007/s002260050003

Burrows, C. H. (1960). Particle Board from Douglas-fir Bark: Without Additives, Oregon Forest Research Center, Corvallis, OR, USA.

Chiang, S.-H. T., and Wang, S.-C. (1984). "The structure and formation of melaleuca bark," Wood and Fiber Science 16(3), 357-373.

Chow, S. (1980). "Wood composite with foliage adhesive", U.S. Patent. Series No. $4,234,658$.

Claude, M., Yemele, N., Blanchet, P., Cloutier, A., and Koubaa, A. (2008). "Effects of bark content and particle geometry on the physical and mechanical properties of 
particleboard made from black spruce and trembling aspen bark," Forest Products Journal 58(11), 48-56.

Halligan, A. F. (1970). "A review of thickness swelling in particleboard," Wood Science and Technology, 4(4), 301-312. DOI: 10.1007/BF00386406

Hashim, R., Said, N., Lamaming, J., Baskaran, M., Sulaiman, O., Sato, M., Hiziroglu, S., and Sugimoto, T. (2011). "Influence of press temperature on the properties of binderless particleboard made from oil palm trunk," Materials \& Design 32(5), 2520-2525. DOI: 10.1016/j.matdes.2011.01.053

Hubbe, M. A., Pizzi, A., Zhang, H., and Halis, R. (2018). "Critical links governing performance of self-binding and natural binders for hot-pressed reconstituted lignocellulosic board without added formaldehyde: A review," BioResources 13(1), 2049-2115. DOI: 10.15376/biores.13.1.Hubbe

Kurokochi, Y., and Sato, M. (2015). "Properties of binderless board made from rice straw: The morphological effect of particles," Industrial Crops and Products 69, 5559. DOI: 10.1016/j.indcrop.2015.01.044

Lakreb, N., As, N., Gorgun, V., Sen, U., Gomes, M. G., and Pereira, H. (2018). "Production and characterization of particleboards from cork-rich Quercus cerris bark," European Journal of Wood and Wood Products 76(3), 989-997. DOI: 10.1007/s00107-017-1284-6

Lasino, and Witarso, W. S. (2014). "Pemanfaatan kayu galam (Melaleuca cajuputi) sebagai lantai yuster untuk rumah sederhana sehat [Utilization of Galam Wood (Melaleuca cajuputi) as a yuster floor for a healthy simple house]," Prosiding Mapeki XVI, Balikpapan, 149-156. [In Indonesian]

Leite, C., and Pereira, H. (2017). "Cork-containing barks-A review," Frontiers in Materials 3, Article number 63. DOI: 10.3389/fmats.2016.00063

Luo, Q.-P., Huang, L., Gao, X., Cheng, Y., Yao, B., Hu, Z., Wan, J., Xiao, X., and Zhou, J. (2015). "Activated carbon derived from melaleuca barks for outstanding high-rate supercapacitors," Nanotechnology 26(30), Article ID 304004. DOI: 10.1088/09574484/26/30/304004

Mantanis, G. I., and Papadopoulos, A. N. (2010). "Reducing the thickness swelling of wood based panels by applying a nanotechnology compound," European Journal of Wood and Wood Products 68(2), 237-239. DOI: 10.1007/s00107-009-0401-6

Morsing, N. (2000). Densification of Wood: The Influence of Hygrothermal Treatment on Compression of Beech Perpendicular to the Grain, Ph.D. Dissertation, Department of Structural Engineering and Materials, Technical University of Denmark, 138 pp.

Nadhari, W. N. A. W., Hashim, R., Hiziroglu, S., Sulaiman, O., Boon, J. G., Salleh, K. M., Awalludin, M. F., Sato, M., and Sugimoto, T. (2014). "Measurement of some properties of binderless composites manufactured from oil palm trunks and Acacia mangium," Measurement 50, 250-254. DOI: 10.1016/j.measurement.2014.01.002

Panyakaew, S., and Fotios, S. (2011). "New thermal insulation boards made from coconut husk and bagasse," Energy and Buildings, 43(7), 1732-1739. DOI: 10.1016/j.enbuild.2011.03.015

Pintiaux, T., Viet, D., Vandenbossche, V., Rigal, L., Rouilly, A. (2015). "Binderless materials obtained by thermo-compressive processing of lignocellulosic fibers: A comprehensive review," BioResources 10, 1915-1963.

Poole, R. T., and Conover, C. A. (1979). "Melaleuca bark and solite as potential potting ingredients for foliage plants," in: Procedings of the 1981 Meeting of the Florida State Horticultural Society, Apopka, FL, USA, pp. 327-329. 
Purwanto, D. (2015). "Sifat papan partikel dari kulit pohon galam (Melaleuca leucadendra) dengan perekat urea formaldehida [The properties of particleboard made of galam (Melaleuca leucadendra L.) tree bark bonded with urea formaldehyde]," Jurnal Penelitian Hasil Hutan 33(2), 135-144. [In Indonesian] DOI: 10.20886/jphh.2015.33.2.135-144

Roussan, P. E. H. (1923). "Application of the bark (suber) of Melaleuca leucadendron to thermic, hydraulic, and dielectric devices," U. S. Patent No. 4058101923.

Sakasegawa, M., Hori, K., and Yatagai, M. (2003). "Composition and antitermite activities of essential oils from Melaleuca species," Journal of Wood Science 49(2), 181-187. DOI: $10.1007 / \mathrm{s} 100860300029$

Sato, M. (2008). "Development of appropriate utilization technology of Melaleuca wood in the Mekong Delta," in: Proceedings of the $10^{\text {th }}$ World Conference on Timber Engineering 2008 (Volume 2), Miyazaki, Japan, pp. 954-961.

SNI 03-2105-2006 (2006). "Papan partikel [Particleboard]," Standardisasi Nasional, Jakarta, Indonesia.

Supriyati, W., Prayitno, T. A., Sumardi, S., and Marsoem, S. N. (2015). "Kearifan lokal penggunaan kayu gelam dalam tanah rawa gambut di Kalimantan Tengah [Local wisdom of utilization of gelam wood on peatswamp land of Central Kalimantan]," Jurnal Manusia dan Lingkungan 22(1), 94-99. DOI: 10.22146/jml.18729

Talib, N. A. A., Zakaria, S., Hua, C. C., and Othman, N. K. (2014). "Tannin bark Melalauca cajuputi powell (gelam) as green corrosion inhibitor of mild steel," AIP Conference Proceedings 1614(1), Article number 171. DOI: 10.1063/1.4895191

Tran, D. B., Dargusch, P., Moss, P., and Hoang, T. V. (2013). "An assessment of potential responses of Melaleuca genus to global climate change," Mitigation and Adaptation Strategies for Global Change 18(6), 851-867. DOI: 10.1007/s11027-0129394-2

Veeramani, V., Madhu, R., Chen, S.-M., Veerakumar, P., Syu, J.-J., and Liu, S.-B. (2015). "Cajeput tree bark derived activated carbon for the practical electrochemical detection of vanillin," New Journal of Chemistry 39(12), 9109-9115. DOI: 10.1039/C5NJ01634G

Xiao, Y., Dong, H., Long, C., Zheng, M., Lei, B., Zhang, H., and Liu, Y. (2014). "Melaleuca bark based porous carbons for hydrogen storage," International Journal of Hydrogen Energy 39(22), 11661-11667. DOI: 10.1016/j.ijhydene.2014.05.134

Zhu, Q., Deng, H., Su, Q., Du, G., Yu, Y., Ma, S., and Xu, B. (2019). “A free-standing nitrogen-doped porous carbon foam electrode derived from Melaleuca bark for lithium-sulfur batteries," Electrochimica Acta 293, 19-24. DOI: 10.1016/J.ELECTACTA.2018.10.017

Article submitted: May 6, 2020; Peer review completed: June 28, 2020; Revised version received and accepted: August 2, 2020; Published: August 7, 2020.

DOI: 10.15376/biores. 15.4.7390-7403 